\section{Scientific journal}

PHYSICAL AND MATHEMATICAL EDUCATION

Has been issued since 2013.

Науковий журнал

ФІЗИКО-МАТЕМАТИЧНА ОСВІТА

Видається $з 2013$.
ISSN 2413-158X (online)

ISSN 2413-1571 (print)

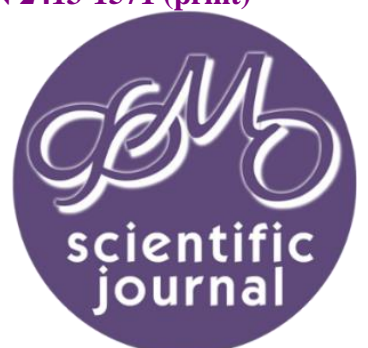

Мар'єнко М.В. Методика використання хмаро орієнтованих систем відкритої науки у процесі навчання професійного розвитку вчителів. Фізико-математична освіта. 2021. Випуск 3(29). С. 99-104.

Marienko M. Methods of using cloud-oriented open science systems in the process of teacher teaching and professional development. Physical and Mathematical Education. 2021. Issue 3(29). P. 99-104.

DOI 10.31110/2413-1571-2021-029-3-015

Удк 378.046.4:: 373.58/.5.091.2.011.3-051:51]:004

М.В. Мар'єнко

Інститут інформачійних технологій і засобів навчання НАПн України, Україна popelmaya@gmail.com

ORCID: 0000-0002-8087-962X

\title{
МЕТОДИКА ВИКОРИСТАННЯ ХМАРО ОРІЄНТОВАНИХ СИСТЕМ ВІДКРИТОЇ НАУКИ У ПРОЦЕСІ НАВЧАННЯ І ПРОФЕСІЙНОГО РОЗВИТКУ ВЧИТЕЛІВ
}

\section{АНОТАЦІЯ}

В статті описано методику використання хмаро орієнтованих систем відкритої науки у процесі навчання $і$ професійного розвитку вчителів. Наведено складники методики використання хмаро орієнтованих систем відкритої науки у прочесі навчання і професійного розвитку вчителів.

Формулювання проблеми. Незважаючи на активне використання освітянами хмаро орієнтованих систем існують певні проблеми в організації навчання та професійного розвитку вчителів. Однією з основних проблем постає відсутність методик використання хмарних сервісів, що не є локалізованими, але безкоштовними для використання в науковій та навчальній діяльності (хмарні сервіси та хмаро орієнтовані системи відкритої науки).

Матеріали і методи. Для досягнення поставленої мети застосовано комплекс методів: порівняльного та системного аналізу наукових праць, що охоплюють проблему дослідження, вивчення вітчизняного та зарубіжного досвіду використання хмаро орієнтованих систем відкритої науки; синтез, узагальнення й концептуалізація для обгрунтування теоретичних засад використання хмаро орієнтованих систем відкритої науки.

Результати. Описана методика є частиною хмаро орієнтованої методичної системи підготовки вчителів природничоматематичних предметів до роботи в науковому ліцеї. Методика використання хмаро орієнтованих систем відкритої науки у процесі навчання і професійного розвитку вчителів містить наступні компоненти: цільовий, змістовий, технологічний та результативний. Визначено, що в якості основного засобу навчання виступає європейська хмара відкритої науки.

Висновки. Використання вчителями хмаро орієнтованих систем відкритої науки у процесі навчання і профресійного розвитку може призвести до впровадження хмаро орієнтованих систем відкритої науки в шкільну практику, використання окремого інструментарію в рамках шкільних предметів, що урізноманітнить навчальний процес та призведе до підвищення його науковості.

КЛЮчОВІ СЛОВА: хмаро орієнтовані системи, відкрита наука, професійний розвиток вчителів, хмаро орієнтовані системи відкритої науки, методика використання хмаро орієнтованих систем.

ВСТУП

Постановка проблеми. У виступі Л. С. Мандзій (Мандзій, 2020), заступниці Міністра освіти і науки України, було розкрито основні можливості підвищення кваліфікації педагогічних працівників. До основних змін професійного розвитку педагога віднесено вільний вибір педагогічними працівниками семінарів, тренінгів, практикумів, вебінарів в межах програми підвищення кваліфікації. Відтак, серед напрямів підвищення кваліфікації було вказано: використання інформаційно-комунікаційних та цифрових технологій; формування та підвищення професійних компетентностей, опанування новітніх технологій. В зв'язку зі змінами підвищення кваліфікації освітян, зокрема вчителів, постає проблема в розробці нових методик, які б змогли охопити принаймні вказані два напрями підвищення кваліфікації. О. В. Коротун в своєму дослідженні (Коротун, 2018) зробила висновок, що використання хмаро орієнтованих систем має величезний потенціал у навчанні, зокрема у навчанні майбутніх вчителів інформатики. Однак, методик використання хмаро орієнтованих систем недостатньо. Якщо за 2018-2021рр. ситуація з впровадження та використання хмаро орієнтованих систем покращилась (Волошина, 2018; Вакалюк, 2019; Кузьмінська, 2020), то використання хмаро орієнтованих систем відкритої науки потребують подальшого розроблення, зокрема у процесі навчання і професійного розвитку вчителів.

(C) М.В. Мар'єнко, 2021. 
В зв'язку із запровадженням карантинних заходів спричинених розповсюдженням COVID-19 в 2020-2021 pp. в більшості шкіл України було впроваджено дистанційну форму навчання. Організація дистанційної форми навчання можлива за рахунок використання інструментів хмаро орієнтованих систем відкритої науки. Незважаючи на активне використання освітянами хмаро орієнтованих систем існують певні проблеми в організації навчання та професійного розвитку вчителів. Однією з основних проблем постає відсутність методик використання хмарних сервісів, що не $\epsilon$ локалізованими, але безкоштовними для використання в науковій та навчальній діяльності (хмарні сервіси та хмаро орієнтовані системи відкритої науки). Існує припущення, що використання хмаро орієнтованих систем відкритої науки дозволить зробити навчальний процес більш науковим та академічним, призведе до вирішення окремих проблем академічної доброчесності серед вчителів та учнів.

Аналіз актуальних досліджень. О. Г. Кузьмінська в своєму дослідженні (Кузьмінська, 2020) аналізує зміст понять «методика використання IKT в освіті» та надає авторське визначення терміну «методика застосування цифрового освітнього середовища наукової комунікації магістрів-дослідників». Описана методика включає: суб'єкти, об'єкти, мету, умови, засоби, форми організації, методи освітньо-наукової комунікації та результат.

Т. А. Вакалюк визначила основні компоненти методичної системи використання хмаро орієнтованого навчального середовища підготовки бакалаврів інформатики включає такі методики (Вакалюк, 2019): методика використання хмаро орієнтованої системи підтримки навчання як складника ХОНС у підготовці бакалаврів інформатики, методика використання хмаро орієнтованих засобів навчання у підготовці бакалаврів інформатики, методика використання Webорієнтованих засобів навчання бакалаврів інформатики.

В дослідженні С.Г.Литвинової (Литвинова, 2016) розроблена методична система проектування хмаро орієнтованого навчального середовища закладу загальної середньої освіти, тому основний акцент полягає в описі методики проектування хмаро орієнтованого навчального середовища закладу загальної середньої освіти. При цьому розглянуто проектування на рівні керівника, проектування на рівні адміністратора навчального середовища, проектування на рівні вчителя-предметника, проектування ХОНС на рівні учня. Хоча в роботі (Литвинова, 2016) відсутня методика використання хмаро орієнтованого навчального середовища закладу загальної середньої освіти, але для проведення поточного дослідження важливим був аналіз методичних основ використання спроектованого хмаро орієнтованого навчального середовища у закладі загальної середньої освіти.

Т. В. Волошина (Волошина, 2018) описала методику використання гібридного хмаро орієнтованого навчального середовища для формування самоосвітньої компетентності майбутніх фахівців з інформаційних технологій. Подано структуру методики. Додатково наведено опис методики інтеграції ресурсів і сервісів гібридного хмаро орієнтованого навчального середовища у електронні навчальні курси для підтримки самоосвітньої діяльності студентів IT-фаху.

Аналіз останніх досліджень та публікацій було в першу чергу спрямовано на вивчення наявних методик використання, оскільки методики навчання та методики використання мають суттєві відмінності. За своєю структурою методика використання хмаро орієнтованих систем відкритої науки у процесі навчання і професійного розвитку вчителів буде мати схожу, класичну структуру, подібну до наявних методик використання того чи іншого сервісу чи програмного продукту.

Мета статті - розробити методику використання хмаро орієнтованих систем відкритої науки у процесі навчання і професійного розвитку вчителів.

\section{МЕТОДИ ДОСЛІДЖЕННЯ}

Для досягнення поставленої мети застосовано комплекс методів: порівняльного та системного аналізу наукових праць, що охоплюють проблему дослідження, вивчення вітчизняного та зарубіжного досвіду використання хмаро орієнтованих систем відкритої науки; синтез, узагальнення й концептуалізація для обгрунтування теоретичних засад використання хмаро орієнтованих систем відкритої науки.

В статті наведені результати виконання другого етапу (Дослідницький) проєкту «Хмаро орієнтовані системи відкритої науки у навчанні і професійному розвитку вчителів» (2020.02/0310) переможця конкурсу «Підтримка досліджень провідних та молодих вчених» за 2020 р, що фінансується Національним фондом досліджень України. Автор статті $\epsilon$ відповідальним виконавцем проєкту «Хмаро орієнтовані системи відкритої науки у навчанні і професійному розвитку вчителів».

\section{РЕЗУЛЬТАТИ ДОСЛІДЖЕННЯ}

Сфера вищої освіти є середовищем, де відкрита наука та відкрита освіта можуть мати взаємозв'язки в межах спільної концепції відкритості. Більш того, відкрита наука та відкрита освіта пов'язані між собою такими суб'єктами, як викладачі закладів вищої освіти, які задіяні в науково-дослідному процесі. Існують деякі ключові компоненти відкритості у відкритій науці, які мають зв'язки з відкритою освітою. Більше того, ці аспекти також можуть бути пов'язані з науководослідною та освітньою діяльністю. Одним із компонентів $\epsilon$ інструменти, тобто системи та послуги - переважно цифрові - які підтримують спілкування та співпрацю в науковій спільноті. Відкритість у цьому сенсі може стосуватися доступності інструменту, його вартості або сумісності з іншими послугами. Багато дослідників називають інструменти та програмне забезпечення з відкритим кодом послугами, які є доступними, модифікуються та мають вільний (повторно) використаний код. Таким чином, відкриті джерела дослідницьких інструментів легко та доступно використовувати для навчання та викладання та можуть полегшити доступ до даних досліджень та джерел для студентів чи учнів. Другий компонент - це діяльність, така як особиста поведінка та взаємодія науковців, як спілкування та співпраця в наукових спільнотах. Діяльність може бути видимою для всіх, обмеженою для певних груп або закритою, як наприклад, процеси сліпого рецензування. Пристосовуючи їх до навчального процесу, наукова діяльність може стосуватися або поведінки вчителів, або поведінки учнів. Актуальними аспектами для учнів $є$ варіанти створення та обміну власними матеріалами та обговорення їх з однолітками. Третім компонентом є такі ресурси, як дані, книги чи наукові статті (Heck et al, 2020). 
Аналізуючи опис методики використання науково-навчальної хмари наукової (освітньої) установи та методики використання компонентів навчального призначення на базі гібридної хмари AWS наведені в дослідженні М. П. Шишкіної (Шишкіна, 2016) було виконано опис методики використання хмаро орієнтованих систем відкритої науки у процесі навчання і професійного розвитку вчителів.

Структура методики використання хмаро орієнтованих систем відкритої науки у процесі навчання і професійного розвитку вчителів.

\section{Цільовий компонент.}

Meта: підвищення рівня навчання і професійного розвитку вчителів за рахунок використання хмаро орієнтованих систем відкритої науки, підвищення рівня компетентностей відкритої науки.

Цільова група: вчителі природничо-математичних предметів.

Змістовий компонент.

Елементи змісту перепідготовки, підвищення кваліфікації вчителів природничо-математичних предметів.

Технологічний компонент.

Методи навчання: спостереження, демонстрація, ілюстрація, репродуктивний, пошуковий, дослідницький, навчальна дискусія; ситуація пізнавальної новизни; ситуація зацікавленості, проблемно-евристичний.

Форми навчання: тренінги, навчальні курси, дистанційні навчальні курси, семінари, вебінари, індивідуальні консультації, лекція (традиційна, проблемна) із застосуванням хмарних сервісів та систем відкритої науки.

Засоби навчання: хмаро орієнтовані системи відкритої науки (хмарні сервіси хмари відкритої науки EOSC, Google Classroom Skype).

Результативний компонент: підвищення рівня навчання і професійного розвитку вчителів за рахунок використання хмаро орієнтованих систем відкритої науки, підвищення рівня компетентностей відкритої науки.

Мінімальні вимоги до апаратно-програмного забезпечення на пристрої користувача: наявність браузера та підключення до мережі Інтернет (дротове чи Wi-Fi).

Орієнтовний план тренінгових занять.

Тема 1. Реєстрація в EOSC та створення проєкту (4 год.).

Тема 2. Добір та додавання окремих хмарних сервісів (4 год.).

Тема 3. Використання загальногалузевих хмарних сервісів (2 год.).

Тема 4. Використання спеціалізованих хмарних сервісів (2 год.).

Всього: 12 год.

Запровадження даної методики рекомендується на вищому рівні хмаро орієнтованої методичної системи підготовки вчителів природничо-математичних предметів до роботи в науковому ліцеї. Рекомендовано проведення окремого курсу (очного чи дистанційного ) підвищення кваліфікації вчителів природничо-математичних предметів. При цьому його специфіка полягає у виключному використанні інструментарію EOSC. Курс підвищення кваліфікації $з$ використання інструментарію EOSC вчителями бажано проводити тривалістю більше ніж тиждень, оскільки окремі хмарні сервіси, які користувач додає до свого проєкту потребують перевірки та ліцензійної згоди. Цей процес може тривати від одного дня до трьох.

Попередньо треба провести підготовчу роботу, пояснивши, що робота буде відбуватись в англомовному середовищі, тому можливо, знадобиться залучення сторонніх програмних засобів (автоматичних та напівавтоматичних перекладачів). Тому, основні моменти використання краще подати, як зразок покрокової роботи з EOSC у вигляді довідкових чи навчально-довідкових матеріалів. Як варіант розробити спеціальні зошити з нотатками де кожен слухач курсів зможе записати індивідуальні спостереження роботи з інструментарієм EOSC. Велику увагу слід приділити демонстраційному матеріалу, що буде використаний під час лекцій. Це може бути як презентація з аудіо супроводом, так і попередньо записане відео (короткий довідковий матеріал).

Також вчителі мають бути ознайомлені з подробицями створення проєкту та спланувати його наповнення. Ці моменти $€$ більш організаційного характеру, однак потребують додаткових роз'яснень та консультацій. Слухачі курсу попередньо визначають структуру майбутнього проекту, його цілі, задачі та проблеми які будуть вирішені після його створення.

Під час вивчення тем 3 та 4 ознайомити слухачів з категоріями сервісів, що наявні в структурі EOSC та пояснити, що в першу чергу вони орієнтовані на науковців. Однак більшість з них можуть бути використані для організації спільної роботи учнів на уроках, для налагодження комунікації. Окремою категорією постають сервіси, які скоріше нагадують репозитарії наукових досліджень. Дані сервіси відкритого доступу будуть також корисні педагогам, оскільки представляють собою останні новинки провідних досліджень Європи, вчителі зможуть ознайомитись з зарубіжними аналогами безкоштовних хмарних сервісів відкритої науки.

Як приклад можна навести короткий опис та використання одного з хмарних сервісів, що представлений в EOSC 3DBionotes-WS. Веб-платформа 3DBionotes-WS інтегрує кілька веб-служб та інтерактивний веб-переглядач, щоб забезпечити єдине середовище, в якому біологічні анотації можна аналізувати в їх структурному контексті. Після спалаху COVID-19 нові структурні дані багатьох вірусних білків були включені в новий розділ 3DBionotes-COVID-19 (рис. 1).

Модель $€$ динамічною. За допомогою кнопок навігації користувач може додавати окремі елементи, переглядати підписи. Наводячи мишкою на окремі елементи моделі з'являється підпис з поясненням. Хмарний сервіс надає можливість самостійно створювати структурні моделі, завантажувати вже готові чи переглядати наявні.

Слухачів слід орієнтувати на те, що всі сервіси Європейської хмари відкритої науки не можна опанувати в рамках курсів підвищення кваліфікації. Головне, щоб вчителі запам'ятали основи роботи з ЕОSC, етапи створення власного проекту та додавання до нього хмаро орієнтованих сервісів, що представлені в переліку за категоріями. 


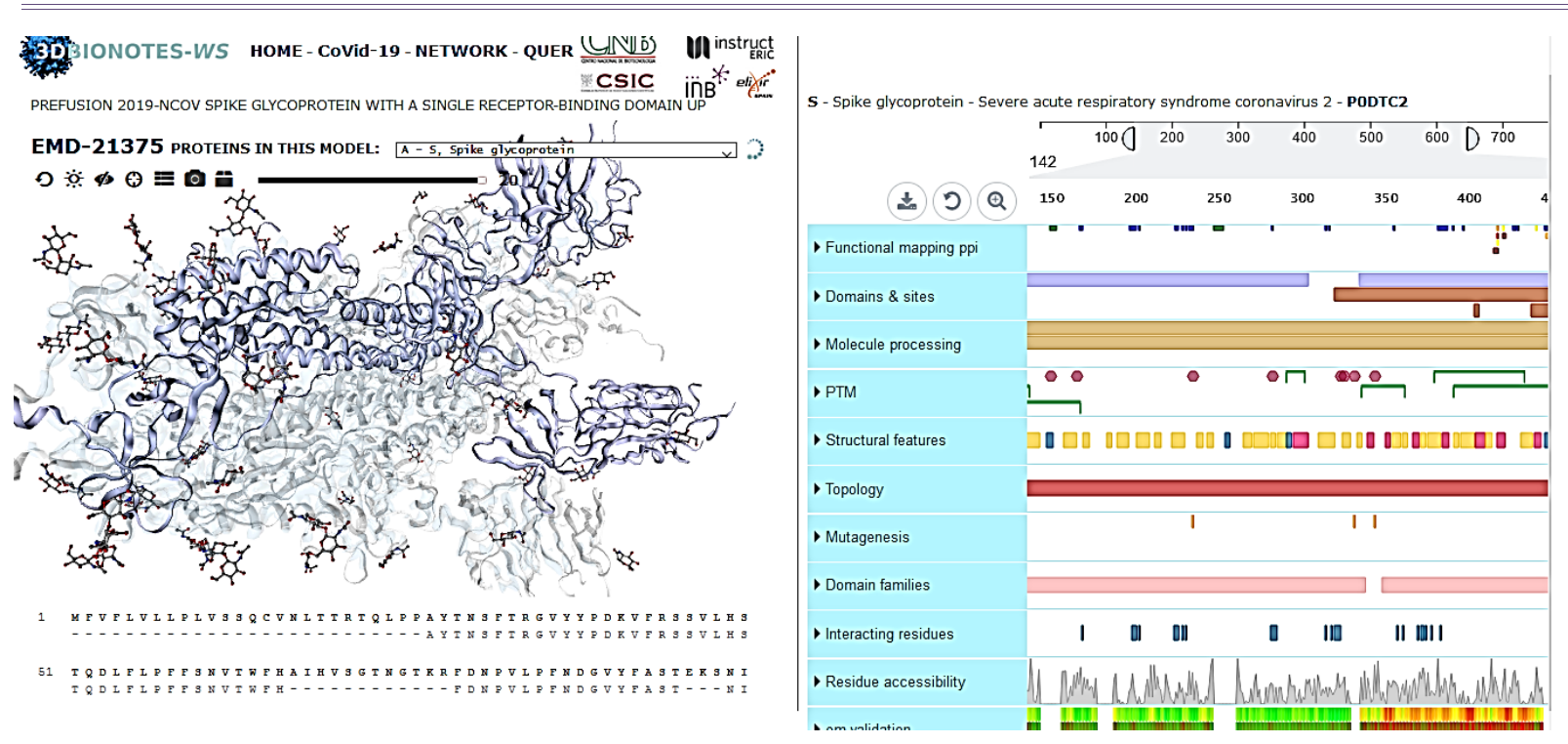

Рис. 1. Приклад структурної моделі

Під час проведення тренінгових занять можуть виникати певні труднощі:

1. Попередньо треба попереджати технічну підтримку того чи іншого хмарного сервісу, адже одночасне використання великої кількості користувачів з України (близько 1000), може бути розцінене як DoS-атака. Це призводить до тимчасового відключення акаунтів користувачів чи повного блокування послуг за локалізацією.

2. Якщо все ж хмарний сервіс тимчасово заблоковано йому має бути надана альтернатива (можливо гнучкий графік виконання завдань з використанням того чи іншого сервісу).

3. Можливий варіант, коли в окремій місцевості відсутнє повне чи часткове інтернет-з'єднання, а учасники тренінгових занять обмежені часовими рамками.

4. Треба бути готовими, що той чи інший акаунт користувача може бути заблоковано чи видалено. Ця проблема особливо актуальна під час організації групової роботи.

5. Слід врахувати той момент, що за певних технічних причин акаунт того чи іншого користувача не буде одразу доступним для роботи (підключення іншими учасниками тренінгових занять).

6. Учасникам тренінгових занять слід попередньо пояснити, чому обрано саме ті чи інші хмарні сервіси, чим вони відрізняються, в чому їх особливість та чому їх слід вважати відкритими. Хоча попередньо вчителі вивчають парадигму відкритої науки, але не одразу стає зрозумілим як це використати на приктиці.

\section{ВИСНОВКИ ТА ПЕРСПЕКТИВИ ПОДАЛЬШОГО ДОСЛІДЖЕННЯ}

В процесі дослідження було встановлено, що існує взаємозв'язок між відкритою наукою та відкритою освітою, що цілі та принципи відкритої науки можна впровадити в закладах вищої освіти. Хмаро орієнтовані системи відкритої науки майже не використовуються в закладах вищої освіти та на курсах підвищення кваліфікації вчителів. Тобто існують проблеми з використання хмаро орієнтованих систем відкритої науки через недостатню розробленість методик їх використання. Методика використання хмаро орієнтованих систем відкритої науки у процесі навчання і професійного розвитку вчителів має включати такі засоби навчання, щоб охопити різні потреби вчителів залежно від форми та предметів викладання.

Описана методика $є$ частиною хмаро орієнтованої методичної системи підготовки вчителів природничоматематичних предметів до роботи в науковому ліцеї. Методика використання хмаро орієнтованих систем відкритої науки у процесі навчання і професійного розвитку вчителів містить наступні компоненти: цільовий, змістовий, технологічний та результативний.

Використання вчителями хмаро орієнтованих систем відкритої науки у процесі навчання і професійного розвитку може призвести до впровадження хмаро орієнтованих систем відкритої науки в шкільну практику, використання окремого інструментарію в рамках шкільних предметів, що урізноманітнить навчальний процес та призведе до підвищення його науковості.

В якості перспективи подальших досліджень постає обґрунтування методичних рекомендацій щодо використання сервісів хмаро орієнтованої методичної системи у процесі діяльності вчителя наукового ліцею, що $€$ одним із запланованих завдань Підсумкового етапу виконання проєкту «Хмаро орієнтовані системи відкритої науки у навчанні і професійному розвитку вчителів» (2020.02/0310).

\section{Список використаних джерел}

1. ВакалюкТ.А. Теоретико-методичні засади проектування і використання хмаро орієнтованого навчального середовища у підготовці бакалаврів інформатики : дис. ... д-ра пед. наук : 13.00 .10 / Інститут інформаційних технологій і засобів навчання НАПН України. Київ, 2019. 614 с.

2. Волошина Т.В. Використання гібридного хмаро орієнтованого навчального середовища для формування самоосвітньої компетентності майбутніх фахівців з інформаційних технологій : дис. ... канд. пед. Наук : 13.00 .10 / Інститут інформаційних технологій і засобів навчання НАПН України. Київ, 2018. 293 с. 
3. Коротун О. В. Використання хмаро орієнтованого середовища у навчанні баз даних майбутніх учителів інформатики : дис. ... канд. пед. наук : 13.00.10 / Житомирський державний університет імені Івана Франка, Інститут інформаційних технологій та засобів навчання НАПН України. Київ, 2018. 356 с.

4. Кузьмінська О.Г. Теоретико-методичні засади проєктування і застосування цифрового освітнього середовища наукової комунікації магістрів-дослідників : дис. ... д-ра пед. наук : 13.00.10 / Національний університет біоресурсів і природокористування України, Державний заклад «Луганський національний університет імені Тараса Шевченка». Старобільськ, 2020. 684 с.

5. Литвинова С.Г. Теоретико-методичні основи проектування хмаро орієнтованого навчального середовища загальноосвітнього навчального закладу : дис. ... д-ра пед. наук : 13.00.10 / Інститут інформаційних технологій і засобів навчання НАПН України. Київ, 2016. 602 с.

6. МандзійЛ.С. Професійний розвиток педагога: нові можливості у 2020. URL:https://nus.org.ua/wpcontent/uploads/2020/03/Prezentatsiya-MON-Pidvyshhennya-kvalifikatsiyi-pedagogiv-ZZSO.pdf $\quad$ (Дата звернення 31.05.2021).

7. Шишкіна М. П. Теоретико-методичні засади формування і розвитку хмаро орієнтованого освітньо-наукового середовища вищого навчального закладу : дис. ... д-ра пед. наук : 13.00.10 / Інститут інформаційних технологій і засобів навчання НАПН України. Київ, 2016. 441 с.

8. Heck T., Peters I., Mazarakis A., Scherpc A., Blümel I. Open Science Practices in Higher Education : Discussion of Survey Results from Research and Teaching Staff in Germany. Education for Information. 2020. No. 36. P. 301-323. DOI: 10.3233/EFI-190272.

\section{References}

1. Vakaliuk, T. A. (2019). Teoretyko-metodychni zasady proektuvannia i vykorystannia khmaro oriientovanoho navchalnoho seredovyshcha u pidhotovtsi bakalavriv informatyky [Theoretical and methodical principles of the cloud-based learning environment design and use in the training of bachelors in computer science]. Doctor's thesis. Kyiv: Institute of Information Technologies and Learning Tools of NAES of Ukraine [in Ukrainian].

2. Voloshyna T. V. (2018) Vykorystannia hibrydnoho khmaro oriientovanoho navchalnoho seredovyshcha dlia formuvannia samoosvitnoi kompetentnosti maibutnikh fakhivtsiv z informatsiinykh tekhnolohii [The use of a hybrid cloud-based learning environment for the formation of self-educational competence of future information technology professionals]. Candidate's thesis. Kyiv: Institute of Information Technologies and Learning Tools of NAES of Ukraine [in Ukrainian].

3. Korotun O. V. (2018). Vykorystannia khmaro oriientovanoho seredovyshcha u navchanni baz danykh maibutnikh uchyteliv informatyky [Use of the cloud-oriented environment in training of databases of future teachers of computer science]. Candidate's thesis. Kyiv : Zhytomyr State University named after Ivan Franko, Institute of Information Technologies and Learning Tools of the National Academy of Pedagogical Sciences of Ukraine [in Ukraine].

4. Kuzminska O. G. (2020). Teoretyko-metodychni zasady proiektuvannia i zastosuvannia tsyfrovoho osvitnoho seredovyshcha naukovoi komunikatsii mahistriv-doslidnykiv [Theoretical and methodical principles of design and application of digital educational environment of scholarly communication of masters of research]. Doctor's thesis. Starobilsk: National University of Life and Environmental Sciences of Ukraine, Institution «Taras Shevchenko National University of Luhansk» [in Ukraine].

5. Lytvynova S. H. (2016) Teoretyko-metodychni osnovy proektuvannia khmaro oriientovanoho navchalnoho seredovyshcha zahalnoosvitnoho navchalnoho zakladu [Theoretical and methodological bases of designing a cloud-based educational environment of a secondary school]. Doctor's thesis. Kyiv: Institute of Information Technologies and Learning Tools of NAES of Ukraine [in Ukrainian].

6. Mandzii L. S. Profesiinyi rozvytok pedahoha: novi mozhlyvosti u 2020 [Professional development of a teacher: new opportunities in 2020]. Retrieved from https://nus.org.ua/wp-content/uploads/2020/03/Prezentatsiya-MONPidvyshhennya-kvalifikatsiyi-pedagogiv-ZZSO.pdf [in Ukrainian].

7. Shyshkina M. P. (2016) Teoretyko-metodychni zasady formuvannia i rozvytku khmaro oriientovanoho osvitno-naukovoho seredovyshcha vyshchoho navchalnoho zakladu [Theoretical and methodological principles of formation and development of cloud-oriented educational and scientific environment of higher education]. Doctor's thesis. Kyiv: Institute of Information Technologies and Learning Tools of NAES of Ukraine [in Ukrainian].

8. Heck, T., Peters, I., Mazarakis, A., Scherpc, A. \& Blümel I. (2020). Open Science Practices in Higher Education : Discussion of Survey Results from Research and Teaching Staff in Germany. Education for Information, 36, 301-323. DOI: 10.3233/EFI190272 [in English].

\section{METHODS OF USING CLOUD-ORIENTED OPEN SCIENCE SYSTEMS IN THE PROCESS OF TEACHER TEACHING AND PROFESSIONAL DEVELOPMENT Maiia Marienko}

Institute of Information Technologies and Learning Tools of NAES of Ukraine, Ukraine

Abstract. The article describes the method of using cloud-based systems of open science in the process of teaching and professional development of teachers. The components of the methodology of using cloud-oriented systems of open science in the process of teaching and professional development of teachers are given.

Formulation of the problem. Despite the active use of cloud-based systems by educators, there are some problems in the organization of teaching and professional development of teachers. One of the main problems is the lack of methods for using cloud services, which are not localized, but free for use in research and educational activities (cloud services and cloud-based open science systems).

Materials and methods. To achieve this goal, a set of methods is used: comparative and systematic analysis of scientific papers, covering the problem of research, study of domestic and foreign experience in the use of cloud-based systems of open science; synthesis, generalization and conceptualization to substantiate the theoretical foundations of the use of cloud-based systems of open science.

Results. The described technique is a part of a cloud-oriented methodical system of preparation of teachers of natural and mathematical subjects 
for work in a scientific lyceum. The method of using cloud-based systems of open science in the process of teaching and professional development of teachers contains the following components: target, content, technology and effectiveness. It is determined that the main cloud of learning is the European cloud of open science.

Conclusions. Teachers' use of cloud-based open science systems in the process of teaching and professional development can lead to the introduction of cloud-based open science systems in school practice, the use of separate tools in school subjects, which will diversify the educational process and increase its scientificity.

Key words: cloud-oriented systems, open science, professional development of teachers, cloud-oriented systems of open science, methods of using cloud-oriented systems. 